\title{
Acceptability of Spiced Plantain Chips among Visitors in Selected Tourist Centres in Ibadan, Oyo State, Nigeria
}

\author{
F. Ajani, D. O. Oshibanjo, and J. O. Oyebade
}

\begin{abstract}
Plantain chips is one of the products obtained from plantain. It is a popular snack among tourists and readily available in most tourist centres in some parts of Africa (such as Nigeria, Cameroon, Ghana, and Côte d'Ivoire). Plantain chips is a local snack and belongs to the category of chips. Chips generally are classified as unhealthy snacks which may contribute to health related problems if consumed in large quantity. This study aimed at assessing the acceptability of spiced plantain chips with onions and dry pepper among tourists in the University of Ibadan Zoological garden and Agodi gardens, Ibadan, Oyo State, Nigeria. A Pilot study was conducted before the execution of the main research. Seven samples of plantain chips were prepared in which five of the samples was spiced with onions and dry pepper (Ata ijosi) at different inclusion levels (2\% and $4 \%$ ) while two served as positive and negative control. A class of sensory evaluation test (Affective test) was used to assess the organoleptic characteristics of the samples. A panel of twenty people which comprised of lecturers and students of the Department of Wildlife and Ecotourism Management was set up for the assessment. The result showed that plantain chips samples at $2 \%$ inclusion levels of onions and dry pepper were mostly preferred for the pilot study and this was used for the main study. For the positive and negative control samples, the negative control was preferred over the positive control and this served as the control for the main study. Thus, three samples (sample A, B and C) were prepared for the main study in which two samples, $A$ and $B$ were spiced with onions and dry pepper while sample $C$ served as the control. 210 copies of Questionnaire (105 in each tourist centre) and Sensory Evaluation Forms were administered to tourists in both tourists' centres using Convenience sampling technique. Data collected were subjected to descriptive (frequency and percentages) and inferential statistics (Analysis of variance and Multiple Linear Regression) using the SPSS software. The result of the sensory evaluation test among tourists revealed that the samples were significantly different in their sensory attributes from the control sample. Tourists preferred the spiced samples, $A$ and $B$ to the control sample, C. However, Sample A was mostly preferred with respect to its aroma, flavour, taste and overall acceptability. The result showed that spicing plantain chips with onions and dry pepper, especially onions may increase its consumption among tourists.
\end{abstract}

Index Terms - Agodi gardens, Spiced Plantain chips, Tourists, University of Ibadan Zoological garden.

\section{INTRODUCTION}

In recent years, tourism has boomed into an eyecatching industry across the world because of its

\footnotetext{
Published on December 17, 2020.

F. Ajani, Department of Wildlife and Ecotourism Management, University of Ibadan, Nigeria.

(e-mail: funmilolajani ${ }^{\circledR}$ yahoo.com)

D. O. Oshibanjo, Department of Animal Science, University of Ibadan, University of Jos, Nigeria.

J. O. Oyebade, Department of Wildlife and Ecotourism Management,

University of Ibadan, Nigeria.
}

significant role in stimulating consumption, promoting trade, and enhancing international communication. Many countries in Asia, Latin America, and Sub-Saharan Africa place a huge weight on the economic impacts of tourism [19]. Tourism is principally a service-based industry and the main product provided by tourism business is hospitality. The hospitality industry is a principal element of the tourism industry and considered to be one of the fastest growing industries worldwide contributing $10 \%$ to the world's gross domestic product. Hospitality is a fundamental feature of human life, and hospitableness indicates the willingness to be hospitable for its own sake, without any expectation of recompense or reciprocity [17] and [18]. It can be considered as a production and service industry. Preparing food and drink is under production industry while providing accommodation and serving prepared food and beverages are under service industry.

Food has been associated with travel from prehistoric times [5]. The relationship between food and tourism has progressed from traditional hospitality, cuisine, and gastronomy to the development of the innovative concept of food tourism [13]. According to [19], every tourist is a voye5ring gourmand. To survive in the first place, every tourist as an organism is in need of eating and drinking. This shows that food constitute a vital part of the touristic experience. One of the major elements of this important relationship is the development and promotion of local food [10] and [11]. Local food plays an important role as an innovative tourism marketing strategy, and as a tool through which to create economic linkages and development [27]. However, many tourist destinations overlook the potential benefits of promoting food. Instead of portraying food as a key tourist attraction, it is often marketed as part of other services and facilities, or as merely a secondary component of the tourism experience [5]. Also, [22] reported that destinations that use food as one of the products sold to tourists do not always do it effectively.

Plantain chips is one of the most popular products obtained from plantain [8]. It is a popular snack sold in stores or on the streets as vended food (RTE) in some parts of Africa (such as Cameroon, Nigeria, Ghana, and Côte d'Ivoire). It is a favourite snack among tourists and readily available in most tourist centres. In Nigeria, plantain chips is known as "ipekere" and "kpekere" in Southwestern and Eastern part of the country respectively.It is usually prepared by slicing the unripened or slightly ripened plantain with a diameter $(2 \mathrm{~mm}$ thick) in vegetable oil at the temperature between $160-170{ }^{\circ} \mathrm{C}$ for 3 to 5minutes. In some cases, it is spiced with sugar, onions, dry pepper, and other food items in order to enhance its taste. However, its 
acceptability among consumers especially tourists have not been assessed.

Several researches have been carried out on plantain chips, nevertheless, none focused on the acceptability of spiced plantain chips among consumers. [8] determined the effects of Aframomum danielli on the physical, chemical, and microbiological properties of fried plantain chips and its preservative effects. Similarly, [23] determined the effect of deep fat frying using different oils on the proximate, vitamins and mineral contents of unripe plantain. Furthermore, [2] determined the effect of frying temperature and time on the quality characteristics (colour, breaking force and moisture content) of plantain chips. Nevertheless, none of the research focused on the acceptability of spiced plantain chips among consumers especially tourists. Thus, this study aimed at assessing the acceptability of plantain chips spiced with onions and dry pepper among visitors.

\section{A. Hypotheses}

1. $\mathbf{H}_{\mathbf{0}}$ : There is no significant difference in the acceptability of spiced plantain chips based on the organoleptic characteristics (colour, aroma, flavour, taste, crispiness and saltiness).

2. $\mathbf{H}_{\mathbf{0}}$ : There is no significant difference in the overall acceptability of plantain chips spiced with onions and dry pepper.

3. $\mathbf{H}_{\mathbf{0}}$ : There is no significant relationship between tourists' selected personal characteristics and overall acceptability of spiced plantain chips.

\section{B. Limitations}

The following limitations were encountered during the course of the research work:

1. Language barrier:

Most International tourists as at the time of the survey were from Non-English speaking countries and as a result, they were unable to participate in the research.

2. Nigerian's mentality: People were skeptical about eating food they were not acquainted with the source.

\section{MATERIALS AND METHODS}

\section{A. Study Area}

The research was carried out in two Tourist centres (University of Ibadan Zoological garden and Agodi gardens) in Ibadan North local government, Ibadan, Oyo state, Nigeria. Ibadan North Local government is a Local Government Area in Ibadan, Oyo State, Nigeria. The University of Ibadan Zoological Garden was established in 1948 as part of the Department of Zoology in the University. It lies between latitude $0726576^{\circ} \mathrm{N}$ and longitude $0025369970^{\circ}$ E. The Zoo was established primarily to support teaching and research works in the department of Zoology but also used also for conservation of endangered species of animals and entertainment purpose. The Zoo serves as a major point of attraction for tourist who visits the university and has received millions of tourists from its time of creation with a wide array of exotic species from different ecological zones of Nigeria and beyond.
Agodi Gardens (also called Agodi Zoological and Botanical Gardens) is a top notch recreational centre in the city of Ibadan, Oyo state, Nigeria near the Oyo State Secretariat complex. It was originally created in 1967 and managed by the then Western region. The site is located in a serene environment on 150 acres of land and serves as a major site of tourist attraction in Ibadan. It is usually patronized by families during festive periods and weekends. Agodi Gardens has a lot of nice features including a water park, children's play area, rides, picnic spots, restaurant area, a lake and a mini zoo. It is very serene, lush and green; perfect for photo shoots, prewedding shoots, picnics, garden parties, outdoor events, concerts and even weddings.

\section{B. Method of Data Collection}

\section{Purchase of materials}

Unripe plantain, dry pepper, onions, salt, and groundnut oil were purchased at Bodija market, Ibadan, Oyo State.

\section{Preparation of plantain chips}

Plantain chips was prepared in the Department of Wildlife and Ecotourism restaurant, University of Ibadan. The method of [16] was adopted in the preparation of the plantain chips. This method was an improvement of theirs because only the preparation of a control sample was made reference to in their book while two other samples were spiced in this research work with dry pepper and onions to enhance its taste, nutritional content and overall acceptability. Plantain were washed, peeled, sliced into round pieces, and fried at $160^{\circ} \mathrm{C}$.

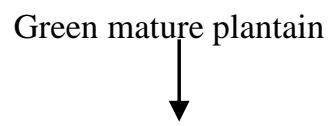

Separation into individual fingers

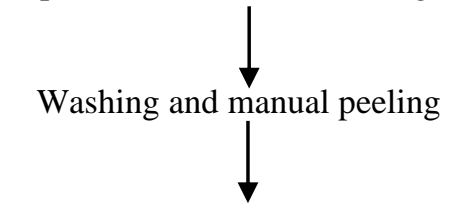

Slicing into round pieces ( $2 \mathrm{~mm}$ thick)

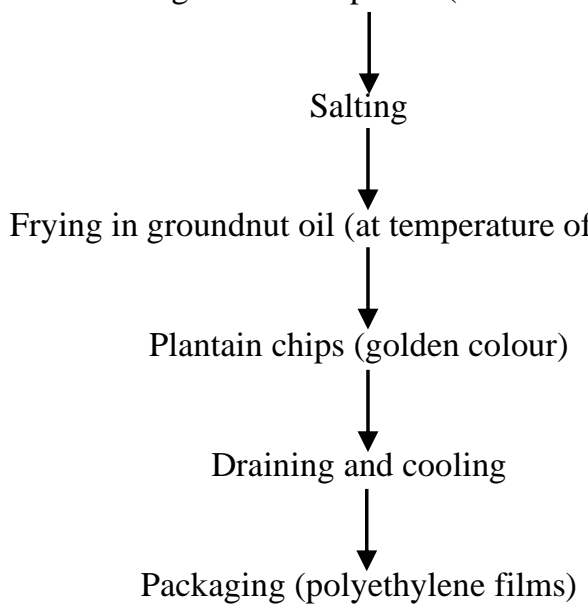

Fig. 1. Flow chart for the preparation of Plantain chips. Source: Adapted from [16].

\section{Pilot experiment}

A Pilot study was conducted in the Department of Wildlife and Ecotourism Management. Seven different 
samples of plantain chips were prepared in which two served as positive and negative control and five of the samples were spiced with onions and dry red pepper (Ata ijosi) at different inclusion levels (2\% and $4 \%$ respectively). The snacks were subjected to sensory evaluation test which was made up of twenty panelists (Lecturers and Students) of the Department. This was executed in order to know the best inclusion level of the spices that is acceptable by the panelists and this was used for the main study. The spices (dry red pepper and onions) were varied at $2 \%$ and $4 \%$ inclusion levels. A class of sensory evaluation test (affective test) was used to measure consumer's response and acceptability level of spiced plantain chips. Also, a questionnaire and Sensory evaluation form was designed to elicit information on the demographic characteristics of respondents and the sensory attributes of plantain chips.

Both dichotomous and multiple-choice questions were included in the questionnaire while hedonic scale with five point ratings from 1-5 (1- Dislike Extremely, 2- Dislike Slightly, 3-Neutral (Neither Like nor Dislike), 4-Like Slightly and 5-Like Extremely) was used to assess the sensory attributes of plantain chips. Section A of the questionnaire addressed questions on the sociodemographic characteristics of respondents such as their Age, Gender, Employment status, Education, Nationality and Marital status. Section B assessed the Consumption pattern of Plantain chips. Section $\mathrm{C}$ served as the sensory evaluation form and this assessed the sensory attributes of plantain chips such as colour, aroma, flavour, taste, crispiness, saltiness, and overall acceptability.

The result showed that plantain chips samples varied at $2 \%$ inclusion level was the most preferred for the pilot study and this was used for the main study. Furthermore, for the positive and negative control, the negative control sample was preferred, and this served as the control for the main study.

\section{Main experiment}

Three different samples (samples A, B and C), most preferred for the pilot study were prepared in which two out of the samples (samples B and C) were spiced with onions and dry red pepper (table I) and these were replicated twice. For this study, the consumers were the tourists who visited the study areas at the time of the research. Each tourist was provided with three different samples of plantain chips (one control and two spiced samples).

TABLE I: METHOD of PREPARATION OF THE SAMPLES OF PLANTAIN CHIPS

\begin{tabular}{cccc} 
& \multicolumn{3}{c}{ CHIPS } \\
\hline \multirow{2}{*}{ Ingredients } & $\mathrm{A}$ & Samples & $\mathrm{C}$ \\
\cline { 2 - 4 } & 500 & 500 & 500 \\
\hline Plantain $(\mathrm{g})$ & 6.0 & 6.0 & \\
Salt $(\mathrm{g})$ & & 10 & \\
Dry red pepper & & & \\
(Ata ijosi) $(\mathrm{g})$ & 10 & $\mathrm{~B}$ & \\
Onions $(\mathrm{g})$ & &
\end{tabular}

KEY: Sample A= Plantain chips + Onions at 2\% (10 g).

Sample B = Plantain chips + dry pepper at $2 \%(10 \mathrm{~g})$

Sample $\mathrm{C}=$ Negative control (plantain chips only).

\section{Sample size and sampling technique}

The target population for the study consisted of visitors on visitation to the study areas during the execution of the research. Using affective test, a total number of two hundred and ten (105 in each tourist centre) tourists were selected from the study areas using convenience sampling technique. Tourists were selected based on their availability and willingness to participate in the research.

\section{Data Analysis}

Data collected were subjected to descriptive statistics (frequency and percentages) and inferential statistics [One way Analysis of Variance (ANOVA), Multiple Linear Regression and Post hoc was done with Duncan multiple range test (DMRT)] using Statistical Analysis Software (SAS, 2002).

\section{RESULTS AND DISCUSSION}

The result of the Socio-demographic factors of respondents used in the research is reported in Table II. It was observed that more than half $(57 \%)$ of the respondents were male which corroborate the research of Ref. 1 that male gender visit ecotourist destinations than their female counterpart. According to them, the masculine gender likes to explore their environment than the feminine gender. Also, $46.2 \%$ of the respondents were within the age bracket 16-25 years which is consistent with the findings of [3]. [1] opined that youths participate more in tourism activities than other categories of people which is due to their vigorous nature and love for adventure. In addition, it was observed that more than half $(74.3 \%)$ of the respondents were single. This is in accordance with [3] that singles participate more in tourism than the married people.

TABLE II: DEMOGRAPHIC CHARACTERISTICS OF TOURISTS

\begin{tabular}{|c|c|c|}
\hline \multirow{2}{*}{ Variables } & \multicolumn{2}{|c|}{ Tourists } \\
\hline & $\mathrm{F}$ & $\%$ \\
\hline \multicolumn{3}{|l|}{ Gender } \\
\hline Male & 120 & 57.1 \\
\hline Female & 90 & 42.9 \\
\hline \multicolumn{3}{|l|}{ Age } \\
\hline $16-25$ & 97 & 46.2 \\
\hline $26-35$ & 74 & 35.2 \\
\hline $36-45$ & 26 & 12.4 \\
\hline $46-55$ & 10 & 4.8 \\
\hline 56 and above & 3 & 1.4 \\
\hline \multicolumn{3}{|l|}{ Nationality } \\
\hline Black African/American & 2 & 1 \\
\hline Nigerian & 201 & 95.7 \\
\hline Indian & 4 & 1.9 \\
\hline Chinese & 1 & 0.5 \\
\hline Myanmar & 2 & 1.0 \\
\hline \multicolumn{3}{|l|}{ Marital status } \\
\hline Single & 156 & 74.3 \\
\hline Married & 53 & 25.2 \\
\hline Separated & 1 & 0.5 \\
\hline \multicolumn{3}{|l|}{ Employment status } \\
\hline Employed full time & 61 & 29 \\
\hline Self-employed & 57 & 27.1 \\
\hline Out of work & 2 & 1.0 \\
\hline Student & 88 & 41.9 \\
\hline Retired & 2 & 1.00 \\
\hline \multicolumn{3}{|l|}{ Educational qualification } \\
\hline SSCE/GCE & 27 & 12.9 \\
\hline OND/HND & 30 & 14.3 \\
\hline BSC/BA & 100 & 47.6 \\
\hline Masters' degree & 37 & 17.6 \\
\hline Doctorate degree & 3 & 1.4 \\
\hline Professional degree & 3 & 1.4 \\
\hline
\end{tabular}

$* \mathrm{~F}=$ Frequency, $\%=$ Percentage. 
Furthermore, the study also showed that both domestic and international tourists participated in the research, although the population of the domestic tourists (95.7\%) was more than the international tourists (4.4\%). [4], among other researchers also noted this. The low patronage of international tourists may be because of the insecurity issues in the country, which have internationally produced a negative image and labeled the country as an unsafe tourism destination. According to [6], crimes, violent acts and civil unrests are in abundance in Nigeria and this poses threat to the security of the nation. He also added that insecurity lowers or discourages investment level, destroys human and social capital, damages relationship between citizens and the state, and thus undermines democracy and the ability of the state to promote development.

Results on employment status indicated that majority $(41.9 \%)$ of the respondents were students. This may be as a result of the proximity of the study areas to educational institutions: The University of Ibadan and The Polytechnic, Ibadan. More than half (68\%) of the respondents possessed tertiary education. This agrees with the work of [25] that people of high level of education are likely to be more aware of the relevance of tourism in social development.

\section{A. Level of Awareness of Local Snacks by Respondents in the University of Ibadan Zoological Garden and Agodi Gardens}

The result is reported in Table III. It was observed that more than half of the respondents $(52.4 \%)$ were aware of local snacks in the two tourist centres and $47.6 \%$ of the respondents reported that they were not aware of local snacks. This showed that local snacks are readily available in the two tourist centres. However, lack of awareness of some tourists may be attributed to the fact that they were first time visitors in the locations. Respondents also indicated the different types of local snacks available in the two tourist centres in which $42.4 \%$ rated plantain chips as the highest. This is because plantain chips are a popular plantain product readily available in most tourist centres in Nigeria.

Almost all (97.6\%) the respondents have consumed plantain chips before. This is because plantain chips are a popular product sold in stores or on streets as vended food in Nigeria and some parts of Africa such as Cameroon, Ghana, and Côte d'Ivoire [8]. Furthermore, 52.4\% signified that they consume it once in a while $30 \%, 8.1 \%$ and $6.7 \%$ indicated that they consume it weekly, daily and monthly, respectively. Moreover, 52.9\% indicated that they have taken the spiced plantain chips before. It was reported that $36.7 \%$ identified pepper as the most commonly used spice to enhance the taste of plantain chips and $46.2 \%$ indicated that they preferred the spiced plantain chips to the normal one.

\section{B. Result of the sensory evaluation of plantain chips}

The result of the sensory evaluation test of the three samples of plantain chips is presented in tables IV and V. The samples were found to be significantly different in all their sensory attributes (colour, aroma, flavour, taste, crispiness, saltiness, and overall acceptability).
TABLE III: RESPONDENTS' AWARENESS OF LOCAL SNACKS AND

\begin{tabular}{|c|c|c|}
\hline \multicolumn{3}{|c|}{ PLANTAIN CHIPS } \\
\hline Variables & $\mathrm{F}$ & $\%$ \\
\hline \multicolumn{3}{|c|}{ Are you aware of any local snacks in UI } \\
\hline \multicolumn{3}{|c|}{ Zoo and Agodi gardens? } \\
\hline Yes & 110 & 52.4 \\
\hline No & 100 & 47.6 \\
\hline \multicolumn{3}{|l|}{ If yes, please tick } \\
\hline Dodo Ikire & 8 & 3.8 \\
\hline Kokoro & 2 & 1.0 \\
\hline Kuli-kuli & 4 & 1.9 \\
\hline Plantain chips & 89 & 42.4 \\
\hline Kilishi & 7 & 3.3 \\
\hline \multicolumn{3}{|c|}{ Have you ever eaten plantain chips? } \\
\hline Yes & 205 & 97.6 \\
\hline No & 5 & 2.4 \\
\hline \multicolumn{3}{|l|}{ If yes, how often? } \\
\hline Daily & 17 & 8.1 \\
\hline Weekly & 63 & 30.0 \\
\hline Monthly & 14 & 6.7 \\
\hline Once in a while & 110 & 52.4 \\
\hline \multicolumn{3}{|c|}{ Have you ever taken spiced Plantain chips? } \\
\hline Yes & 111 & 52.1 \\
\hline No & 88 & 41.9 \\
\hline \multicolumn{3}{|c|}{ If yes, identify the spice used } \\
\hline Ginger & 3 & 1.4 \\
\hline Onions & 15 & 7.1 \\
\hline Pepper & 77 & 36.7 \\
\hline Salt & 10 & 4.8 \\
\hline Sugar & 5 & 2.4 \\
\hline Yagi & 1 & 0.5 \\
\hline \multicolumn{3}{|c|}{$\begin{array}{l}\text { Do you like the spiced plantain chips } \\
\text { compared to the normal plantain chips? }\end{array}$} \\
\hline Yes & 97 & 46.2 \\
\hline No & 11 & 5.2 \\
\hline
\end{tabular}

$* \mathrm{~F}=$ Frequency, $\%=$ Percentage.

\section{Colour}

There were variations in the colours of all the samples. The control sample had a golden yellow colour which plantain chips is normally characterized with, while the spiced samples (Sample Band C) had different colours (i.e brownish yellow). This may be attributed to the addition of different spices used in their preparation which led to the decrease in color intensity with puffing of samples during frying as well as influence of higher temperatures and times on frying of the snacks. This validates the research of [2] that the colour intensity of plantain chips decreases progressively as the frying temperature and time increased. Generally, the more the frying time, the less the color acceptance of snacks. This shows that changes in colour will lead to lower colour quality on the surface of plantain chips. Therefore, the colour of the control sample (Sample C) was preferred over the spiced samples. This validates the research of [21], that colour is one of the most important quality parameters of fried snacks which is strictly related to consumer's perception. It is considered as one of the attributes critically assessed by consumers and often forms the basis for their selection or rejection of products.

\section{Aroma, flavour, saltiness and taste}

The likeness of the aroma, flavour and taste of the three samples of Plantain chips were totally different. The aroma, flavour and taste of the spiced samples (A and B) were preferred over the control sample. This was because of the inclusion of different spices (onions, salt and dry red pepper) used in their preparation. This is consistent [9] that spices are flavouring substances added to food to enhance savory. They enhance and complement flavor as well as 
taste in foods with no detrimental effect on the organoleptic quality of the food [14]. Also, [24] opined that spices stimulate appetite and create visual appeals to food. This implies that the use of spices on plantain chips is acceptable by tourists and can be used as a tool to attract more tourists to tourist destinations.

\section{Crispiness}

Crispiness is usually associated with the breaking force of a food. It is connected with rapid drop of force during mastication process that, in turn, is based on fracture propagation in brittle materials [20]. When force is applied to brittle snacks, rupture of the cellular structure occurs and in line with some deformation, generates a typical sound contributing to crispness sensation. The likeness of the crispiness of the three samples of plantain chips varied. Although, all the samples had low moisture content, the control sample (sample C) was mostly preferred over the spiced samples. This may be because the control sample was not spiced with anything and during the frying process, the pores of the plantain chips opened up leading to the formation of porous structures which resulted into the high level of crispiness. [28] opined that the more pores in snacks, the more crispness perception. In addition, [26] asserted that crispness of chips is a vital measure that determines consumers' acceptance. It is the most important textural attribute which denotes freshness and high quality.

TABLE IV: SENSORY ATtRIBUtes of All The SAMPLES OF PLANTAIN

\begin{tabular}{|c|c|c|c|c|c|}
\hline \multicolumn{6}{|c|}{ CHIPS } \\
\hline Variables & 1 & 2 & 3 & 4 & 5 \\
\hline \multicolumn{6}{|l|}{ Sample A } \\
\hline Colour & $42(17.60)$ & $88(41.90)$ & $67(31.90)$ & $10(4.80)$ & $3(1.40)$ \\
\hline Aroma & $23(11.00)$ & $81(38.60)$ & $77(36.70)$ & $25(11.90)$ & $4(1.90)$ \\
\hline Flavor & $26(12.40)$ & $74(35.20)$ & $82(39.00)$ & $26(12.40)$ & $2(1.00)$ \\
\hline Taste & $23(11.00)$ & $84(40.00)$ & $70(33.30)$ & $31(14.80)$ & $2(1.00)$ \\
\hline Crispiness & $61(29.00)$ & $86(41.00)$ & $53(25.20)$ & $9(4.30)$ & $1(0.50)$ \\
\hline Saltiness & $20(9.50)$ & $87(41.40)$ & $70(33.30)$ & $27(12.90)$ & $6(2.90)$ \\
\hline \multicolumn{6}{|l|}{ Sample B } \\
\hline Colour & $37(17.60)$ & $69(32.90)$ & $75(35.70)$ & $26(12.40)$ & $3(1.40)$ \\
\hline Aroma & $13(6.20)$ & $62(29.50)$ & $98(46.70)$ & $32(15.20)$ & $5(2.40)$ \\
\hline Flavor & $14(6.70)$ & $54(25.70)$ & $90(42.90)$ & $51(24.30)$ & $1(0.50)$ \\
\hline Taste & $16(7.60)$ & $60(28.60)$ & $93(44.30)$ & $39(18.60)$ & $2(1.00)$ \\
\hline Crispiness & $43(20.50)$ & $82(39.00)$ & $65(31.00)$ & $17(8.10)$ & $3(1.40)$ \\
\hline Saltiness & $19(9.00)$ & $72(34.30)$ & $81(38.60)$ & $35(16.70)$ & $3(1.40)$ \\
\hline \multicolumn{6}{|l|}{ Sample C } \\
\hline Colour & $101(48.10)$ & $41(19.50)$ & $39(18.60)$ & $11(5.20)$ & $18(8.60)$ \\
\hline Aroma & $45(21.40)$ & $37(17.60)$ & $78(37.10)$ & $27(12.90)$ & $23(11.00)$ \\
\hline Flavor & $47(22.40)$ & $41(19.50)$ & $67(31.90)$ & $30(14.30)$ & $25(11.90)$ \\
\hline Taste & $48(22.90)$ & $39(18.60)$ & $70(33.30)$ & $29(13.80)$ & $24(11.40)$ \\
\hline Crispiness & $86(41.00)$ & $45(21.40)$ & $45(21.40)$ & $24(11.40)$ & $10(4.80)$ \\
\hline Saltiness & $28(13.30)$ & $23(11.00)$ & $62(29.50)$ & $38(18.10)$ & $59(28.10)$ \\
\hline \multicolumn{6}{|l|}{ KEY: } \\
\hline \multicolumn{6}{|c|}{$\begin{array}{l}\text { Sample A = Plantain chips + Onions, Sample B = Plantain chips + Pepper } \\
\text { and Sample C = Control. } \\
1=\text { Like Extremely, } 2=\text { Like Slightly, } 3=\text { Neutral, } 4=\text { Dislike Slightly, } 5 \\
=\text { Dislike Extremely. }\end{array}$} \\
\hline
\end{tabular}

According to [7], the overall acceptability of fried foods lies in their unique organoleptic characteristics, including flavour, texture and appearance. This acceptance is critical because of the specific quality attributes that attract people [20]. Generally, the spiced samples were rated higher than the control sample for the overall acceptability. Thus, sample A was mostly preferred over other samples by the tourists and its likeness was basically attributed to the sensory attributes (table V). This showed that the use of spices in the preparation of Plantain chips will lead to an increase in the acceptability among tourists especially the foreigners. This supports the work of [12] that food plays an essential role in tourism and can also serve as an effective tool to promote and position a destination.

TABLE V: Overall ACCEPTABILITy of All the SAMPLES OF Plantain

\begin{tabular}{|c|c|c|}
\hline \multicolumn{3}{|c|}{ CHIPS } \\
\hline Variables & Frequency & Percentages \\
\hline SAMPLE A & & \\
\hline Like extremely & 32 & 15.20 \\
\hline Like slightly & 83 & 39.50 \\
\hline Neutral & 77 & 36.70 \\
\hline Dislike extremely & 17 & 8.10 \\
\hline $\begin{array}{l}\text { Dislike slightly } \\
\text { SAMPLE B }\end{array}$ & 1 & 0.50 \\
\hline Like extremely & 18 & 8.60 \\
\hline Like slightly & 68 & 32.40 \\
\hline Neutral & 98 & 46.70 \\
\hline Dislike extremely & 24 & 11.40 \\
\hline $\begin{array}{l}\text { Dislike slightly } \\
\text { SAMPLE C }\end{array}$ & 2 & 1.00 \\
\hline Like extremely & 15 & 7.10 \\
\hline Like slightly & 28 & 13.30 \\
\hline Neutral & 65 & 31.00 \\
\hline Dislike extremely & 44 & 21.00 \\
\hline Dislike slightly & 58 & 27.60 \\
\hline $\begin{array}{l}\text { Most preferred } \\
\text { sample }\end{array}$ & & \\
\hline Samples & & \\
\hline A & 107 & 51.00 \\
\hline B & 59 & 28.10 \\
\hline $\mathrm{C}$ & 44 & 21.00 \\
\hline Total & 210 & 100 \\
\hline $\begin{array}{l}\text { Reasons for their } \\
\text { preference }\end{array}$ & & \\
\hline Sensory attributes & 70 & 33.33 \\
\hline Taste & 15 & 7.10 \\
\hline Aroma & 7 & 3.33 \\
\hline Colour & 8 & 3.80 \\
\hline Saltiness & 7 & 3.33 \\
\hline
\end{tabular}

KEY:

Sample A= Plantain chips + Onions, Sample B = Plantain chips + Pepper and Sample $\mathrm{C}=$ Control.

\section{Result of the Hypotheses}

\section{Hypothesis 1}

$\mathbf{H}_{\mathbf{0}}$ : There is no significant difference in the tourist acceptability of spiced plantain chips based on the sensory attributes (colour, aroma, taste, flavour, crispiness, saltiness, and overall acceptability).

One-way Analysis of Variance (ANOVA) was used to test for the significant differences that exist among the samples based on their sensory attributes. The result revealed that there was a significant difference among the samples based on their sensory attributes (colour, flavour, aroma, crispiness, and overall acceptability). This shows that the addition of spices on plantain chips has a significant effect on its sensory attributes. Therefore, the null hypothesis was rejected, and the alternative hypothesis was accepted (Table VI).

\section{Hypothesis 2}

$\mathbf{H}_{\mathbf{0}}$ : There is no significant difference in the overall acceptability of plantain chips spiced with onions, dry pepper and the control sample.

One-way Analysis of Variance (ANOVA) was also used to test for the significant differences that exist among the samples based on the spiced plantain chips and the control. The result revealed that there is a significant difference among the samples based on the addition of spices 
Therefore, the null hypothesis was rejected, and the alternative hypothesis was accepted (Table VII).

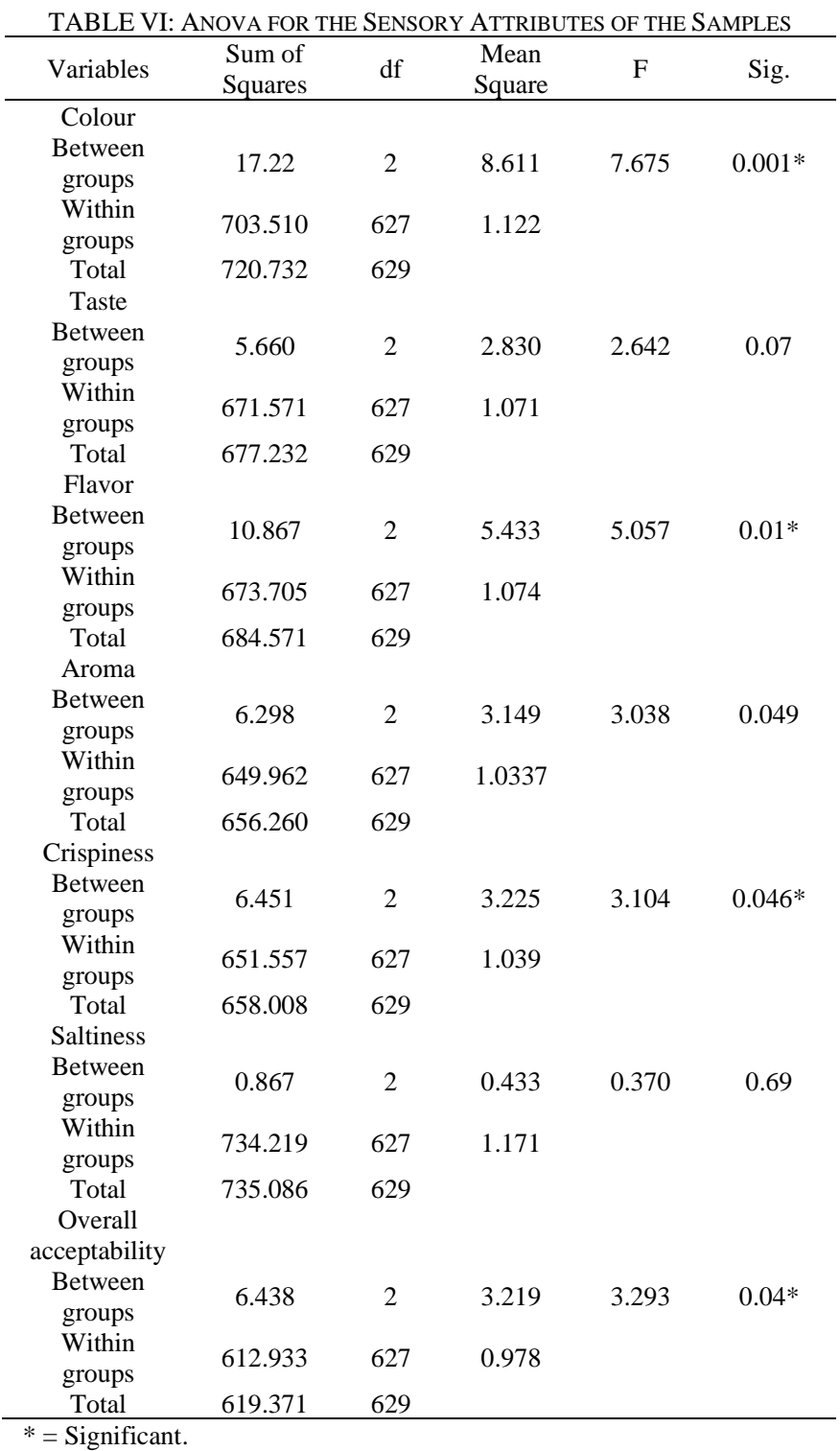

TABLE VII: ANOVA FOR THE OVERALL ACCEPTABILITY OF ALL THE

\begin{tabular}{|c|c|c|c|c|c|}
\hline \multicolumn{6}{|c|}{ SAMPLES } \\
\hline Samples & $\begin{array}{l}\text { Sum of } \\
\text { squares }\end{array}$ & Df & $\begin{array}{c}\text { Mean } \\
\text { square }\end{array}$ & F & Sig. \\
\hline \multicolumn{6}{|l|}{$\mathrm{A}$} \\
\hline $\begin{array}{c}\text { Between } \\
\text { groups }\end{array}$ & 48.39 & 6 & 8.07 & 10.01 & $0.00 *$ \\
\hline $\begin{array}{l}\text { within } \\
\text { groups }\end{array}$ & 1167.48 & 1463 & 0.80 & & \\
\hline $\begin{array}{c}\text { Total } \\
\text { B }\end{array}$ & 1215.87 & 1469 & & & \\
\hline $\begin{array}{c}\text { Between } \\
\text { groups }\end{array}$ & 46.98 & 6 & 7.83 & 9.77 & $0.00 *$ \\
\hline $\begin{array}{l}\text { Within } \\
\text { groups }\end{array}$ & 1172.52 & 1463 & 0.80 & & \\
\hline $\begin{array}{l}\text { Total } \\
\text { C }\end{array}$ & 1219.50 & 1469 & & & \\
\hline $\begin{array}{c}\text { Between } \\
\text { groups }\end{array}$ & 99.766 & 6 & 16.63 & 10.32 & $0.00 *$ \\
\hline $\begin{array}{l}\text { Within } \\
\text { groups }\end{array}$ & 2357.46 & 1463 & 1.61 & & \\
\hline Total & 2457.23 & 1469 & & & \\
\hline
\end{tabular}

KEY:

Sample A = Plantain chips + Onions, Sample B = Plantain chips + Dry pepper and Sample $\mathrm{C}=$ Control

* = Significant.

\section{Hypothesis 3}

$\mathbf{H}_{\mathbf{o}}$ : There is no significant relationship between tourists selected personal characteristics and overall acceptability of spiced plantain chips. Multiple Linear Regression was used to test for the relationship between tourists' sociodemographic characteristics and the overall acceptability of spiced plantain chips and the control sample. The result revealed that there was no significant relationship between tourists' socio-demographic characteristics and their overall acceptability of plantain chips. In other words, gender, age, marital status, nationality, employment status and educational qualification do not influence the level of overall acceptability of plantain chips. Therefore, the null hypothesis was accepted, and the alternative hypothesis was rejected (Table VIII).

TABLE VIII: TEST OF HYPOTHESIS 3 ON ALL THE SAMPLES

\begin{tabular}{|c|c|c|c|c|}
\hline Variables & Beta & $\mathrm{t}$ & $\mathrm{P}$ & Inference \\
\hline \multicolumn{5}{|l|}{ Sample A } \\
\hline Gender & -0.04 & -0.53 & 0.60 & $\begin{array}{c}\text { Not } \\
\text { significant }\end{array}$ \\
\hline Age & 0.05 & 0.50 & 0.62 & $\begin{array}{c}\text { Not } \\
\text { significant }\end{array}$ \\
\hline Nationality & -0.04 & -0.48 & 0.06 & $\begin{array}{c}\text { Not } \\
\text { significant }\end{array}$ \\
\hline Marital status & 0.07 & 0.67 & 0.50 & $\begin{array}{c}\text { Not } \\
\text { significant }\end{array}$ \\
\hline Employed & 0.04 & 0.55 & 0.58 & $\begin{array}{c}\text { Not } \\
\text { significant }\end{array}$ \\
\hline Education & 0.07 & 0.97 & 0.33 & $\begin{array}{c}\text { Not } \\
\text { significant }\end{array}$ \\
\hline \multicolumn{5}{|l|}{ Sample B } \\
\hline Gender & -0.01 & -0.18 & 0.86 & $\begin{array}{c}\text { Not } \\
\text { significant }\end{array}$ \\
\hline Age & 0.00 & 0.04 & 0.97 & $\begin{array}{c}\text { Not } \\
\text { significant }\end{array}$ \\
\hline Nationality & -0.11 & -1.55 & 0.12 & $\begin{array}{c}\text { Not } \\
\text { significant }\end{array}$ \\
\hline Marital status & 0.04 & 0.39 & 0.69 & $\begin{array}{c}\text { Not } \\
\text { significant }\end{array}$ \\
\hline Employed & 0.02 & 0.26 & 0.79 & $\begin{array}{c}\text { Not } \\
\text { significant }\end{array}$ \\
\hline Education & 0.13 & 1.73 & 0.09 & $\begin{array}{l}\text { Not } \\
\text { significant }\end{array}$ \\
\hline \multicolumn{5}{|l|}{ Sample B } \\
\hline Gender & -0.09 & -1.19 & 0.24 & $\begin{array}{c}\text { Not } \\
\text { significant }\end{array}$ \\
\hline Age & -0.10 & -1.04 & 0.30 & $\begin{array}{l}\text { Not } \\
\text { significant }\end{array}$ \\
\hline Nationality & -0.07 & -0.99 & 0.33 & $\begin{array}{c}\text { Not } \\
\text { significant }\end{array}$ \\
\hline Marital status & 0.12 & 1.18 & 0.24 & $\begin{array}{c}\text { Not } \\
\text { significant }\end{array}$ \\
\hline Employed & 0.03 & 0.45 & 0.65 & $\begin{array}{c}\text { Not } \\
\text { significant }\end{array}$ \\
\hline Education & 0.12 & 1.70 & 0.09 & $\begin{array}{c}\text { Not } \\
\text { significant }\end{array}$ \\
\hline
\end{tabular}

\section{CONCLUSION AND RECOMMENDATIONS}

Local snacks form part of the food chain as well as local economy and this can be used as a marketing strategy to promote a destination. Also, like other aspects of tourism such as transportation, accommodation, etc. it can be used to sustain tourism in a destination. Thus, in this research, it was observed that addition of spices (especially onions) in the preparation of plantain chips was acceptable among tourists. However, the level of acceptability of the colour of the spiced samples was low in relation to the control sample. This shows that the respondents preferred the 
colour of the control sample to be maintained in the spiced samples. Therefore, there is need to devise a means of replicating the colour of the control sample in the spiced samples to enhance its attraction and acceptability by consumers. Also, awareness should be created on the use of food to promote a tourist destination and local spices should be used in the preparation of food (especially snacks) because of its nutritional content.

\section{REFERENCES}

[1] Adefalu, L.L., Aderinoyr-Abdulwahab, S.A., Olabanji, O.P., and Tijani, A. 2014. Socio-economic Characteristics of Tourists in University of Ibadan Zoo, Ibadan, Nigeria. Journal of Advances in Agricultural and Environmental Eng. (IJAAEE) Vol. 1:175-178.

[2] Adeyanju, J.A., Olajide, J.O. and Adedeji, A.A. 2016.Optimisation of Deep-Fat Frying of Plantain Chips (Ipekere) using Response Surface Methodology. Journal of Food Processing \& Technology 7:1-6.

[3] Akinyemi, A. F. 2014. Tourist wildlife feeding for pleasure at the University of Ibadan Zoological Garden, Nigeria. African Journal of Hospitality, Tourism and Leisure Vol. 4.2:1-8.

[4] Alarape, A.A., Yager, G.O. and Salman, K.K. 2015. Assessment of tourists satisfaction and perception in Makurdi zoological garden, Benue state, Nigeria. Journal of Research in Forestry, Wildlife and Environmental. Vol. 7.1:1-12.

[5] Boniface, P. 2003. Tasting tourism: Travelling for food and drink. Hampshire: Ashgate Publishing Limited.

[6] Dambazau, Bello A. 2007. Criminology and Criminal Justice. Ibadan, Spectrum Books Limited.

[7] Dana, D. and Saguy, I.S. 2006. Review: Mechanism of oil uptake during deep-fat frying and the surfactant effect-theory and myth. Adv Colloid Interface Sci.128-130:267-272. doi: 10.1016/j.cis.2006.11.013.

[8] Falola A.O, Adegoke A.O and Okoro C.C. 2014. Shelf life extension studies of Fried Plantain Chips Treated with Crude Antioxidants Extracts of Aframomumdanielli. Asian Journal of Agriculture and Food Sciences (ISSN: 2321 - 1571) 2:560-565.

[9] Fry, P. (2009). The Good Cooks. London, Mackmillian Press. Pp 79-80.

[10] Hall, C. M., and Sharples, L. 2003. Consuming places: The role of food, wine and tourism in regional development. In C. M. Hall, L. Sharples, R. Mitchell, N.

[11] Hall, C. M., and Mitchell, R. 2002. The changing nature of the relationship between cuisine and tourism in Australia and New Zealand: from fusion cuisine to food networks. In A.-M. Hjalager and G. Richards (Eds.), Tourism and gastronomy (pp. 186-206). London, UK: Routledge.

[12] Hjalager, A.,and Richards, G. 2002. Still undigested: research issues in tourism and Hudson, S. (1999). Consumer behaviour related to tourism. Consumer behaviour in travel and tourism. Eds. A. P. a. Y. Mansfeld (pp. 7-32). New York: Haworth Press.

[13] Jones, A., and Jenkins, I. 2002. 'A taste of Wales - Blas ArGymru': Institutional malaise in promoting Welsh food tourism products. Tourism and Gastronomy. Eds. A.-M. Hjalagar and G. Richards, pp. 114-131. Oxon, UK: Routledge.

[14] Kaefer, C. M., Milner, J. A. 2011. Herbs and spices in cancer prevention and treatment. Chapter 17. In: Benzie, I. F. F., WachtelGalor, S. (eds.) Herbal Medicine: Biomolecular and Clinical Aspects. CRS Press/Taylor and Francis, Boca Raton, FL.

[15] Lacy, J. and Douglass, W. 2002. Beyond Authenticity: The Meaning and Uses of Cultural Tourism. Tourist Studies 2.: 9-21.

[16] Laniran Abigail M. and AkinsolaAkinjide O. (2015). Nigerian Traditional Recipes and Yeast Cookery. Kingdom Heritage Printing and Publishing Ventures, 20, OjoduBeger, Lagos. Pp.39. ISBN: 978-978-53016-7-0

[17] Lashley, C., and Morrison, A. (Eds.) 2000. In search of hospitality: Theoretical perspectives and debates. Oxford: ButterworthHeinemann. (Cited in Revista Hospitalidade, 2015. Pp. 70-92).

[18] Lashley, C., Lynch, P. and Morrison, A. 2007. Hospitality: an introduction. In C. Lashley and A. Morrison (Eds). Hospitality: A social lens (pp. 1-15). Oxford: Elsevier, http://dx.doi.org/10.1016/B978-0-08-045093-3.50004-7

[19] Lee, C.C. and Chang, C.P. (2008). Tourism development and economic growth: A closer look panels. Tour.Manag. 29:180-192.
[20] Mazumder, P., Roopa, B.S. and Bhattacharya, S. 2007. Textural attributes of a model snack food at different moisture contents. $J$ Food Eng.79:511-516. doi: 10.1016/j.jfoodeng.2006.02.011.

[21] Mendoza, F., Dejmek, P., Aguilera, J.M. 2007. Colour and image texture analysis classification of commercial potato chips. Food Res Int.; 40:1146-1154. doi: 10.1016/j.foodres.2007.06.014.

[22] Okumus, B., Okumus, F., and McKercher, B. 2007. Incorporating local and international cuisines in the marketing of tourism destinations: The cases of Hong Kong and Turkey. Tourism Management, 28, 253-261.

[23] Omolola, Omotosho, Rebecca, Garuba, Femi, Ayoade and Shalom, Nwodo Chinedu 2016. Effect of deep-fat frying using Canola Oil, Soya $\mathrm{Ol}$ and Vegetable Oil on Proximate, Vitamins and Mineral Contents of Unripe Plantain (Musa x paradisiaca). Journal of Applied sciences 16(3):103-107.

[24] Opara, E. I., Chohan, M. 2014. Culinary herbs and spices: their bioactive properties, the contribution of polyphenols and the challenges in deducing their true health benefits. International Journal of Molecular Sciences 15: 19183-19202.

[25] Ritchie, J. R. B., and Crouch, G. 2003. The competitive destination. Wallingford: CABI Publishing

[26] Setiady, D., Tang, J., Younce, F., Swanson, B.A., and Rasco, B.A. 2009. Porosity, colour, texture using microwave vacuum, heated air, and freeze drying. ASABE Appl Engi Agri 25:719-724.

[27] Sharples, L. 2003. Food tourism in the Peak District National Park, England. In Food tourism around the world: Development, management and markets. Oxford, UK: Butterworth-Heinemann.

[28] Tsukakoshi, Y., Naito, S., Ishida, N. 2008. Fracture intermittency during a puncture of cereal snacks and its relation to porous structure. Food Res Int.41:909-917. doi: 10.1016/j.foodres.2007.11.010.

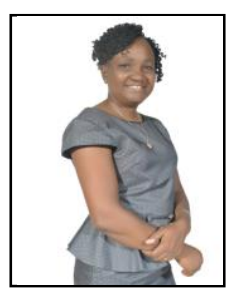

Dr. Funmilola Ajani is an Associate Professor and she lectures in the Department of Wildlife and Ecotourism Management, University of Ibadan, Ibadan, Nigeria. She is in the Ecotourism unit. She is an environmentalist and her research work is focused on water-based tourism, biodiversity and environmental integrity of the recreational sites in Nigeria. Her research is focused on natural resources, the environmental integrity of these resources and those factors militating against them. She has to her credit, over 50 publications in local and international journals.

Dr. Ajani is a member of Society of Toxicology (SOT), USA, Organisation of Women in Science for the Developing world (OWSD), Fisheries Society of Nigeria (FISON), International Society of Organic Agriculture Research (ISOFAR), American Association for Science and Technology (AASCIT) and The International Ecotourism Society (TIES) She won TWAS/CSIR fellowship and she was at the Centre for Cellular and Molecular Biology, India in year 2013 for her postdoctoral fellowship. She was a recipient of Mashav fellowship in year 2012.

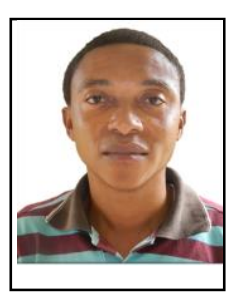

Dr. Olusegun Oshibanjo is a Lecturer 1 and he is currently a lecturer at the Department of Animal Production, Faculty of Agriculture, University of Jos, Jos, Plateau State. He specializes in Natural Products with emphasis on Animal Products and Processing nutrition. He is a seasoned researcher and collaborator with some Institute such as National Veterinary Research Institute. He is into functional foods, making food our drugs, not drugs our food.

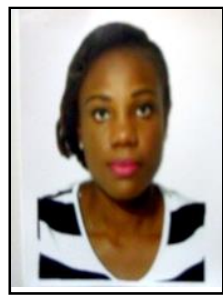

Joy Olufunke Oyebade is currently a Ph.D. student at the University of Ibadan, Ibadan, Oyo State, Nigeria with research interest in hospitality and tourism management. Her focus is on promotion of indigenous foods among tourists in tourism destinations. 